\title{
Motivational factors for a sports ministry: A case study of churches in Pretoria
}

\begin{abstract}
Authors:
Tim Tucker ${ }^{1}$

Noel Woodbridge ${ }^{2}$

Affiliations:

${ }^{1}$ Ambassadors in Sport,

Pretoria, South Africa

${ }^{2}$ South African Theology Seminary, Johannesburg, South Africa

Note:

Tim Tucker recently completed his MTh in Practical Theology and is involved in full-time sports ministry in South Africa.

This article is published in the section Practical Theology of the Society for Practical Theology in South Africa.

\section{Correspondence to:} Noel Woodbridge

Email:

noel@sats.edu.za

Postal address:

PO Box 32136, Glenstantia

0010, South Africa

Dates:

Received: 25 Nov. 2011

Accepted: 05 Feb. 2012

Published: 16 Apr. 2012

How to cite this article: Tucker, T. \& Woodbridge, N., 2012, 'Motivational factors for a sports ministry: A case study of churches in Pretoria', HTS Teologiese Studies/Theological Studies 68(2), \#Art. 1199, 7 pages. http://dx.doi.org/10.4102/ hts.v68i2.1199
\end{abstract}

(C) 2012. The Authors. Licensee: AOSIS OpenJournals. This work is licensed under the Creative Commons Attribution License.
The purpose of this study was to investigate church leaders' perceptions of motivational factors for a sports ministry in churches in Pretoria. A survey questionnaire was developed by the researchers to investigate the above perceptions. The survey consisted of demographic questions and perception questions using a structured and a semi-structured questionnaire. The results of the survey were assessed by calculating the significance of each motivational factor for a sports ministry in the church, as perceived by the respondents. Participants were recruited from 32 church leaders from a wide variety of denominational and cultural backgrounds in Pretoria. Results showed that a sports ministry could assist the church in evangelism and fulfilling the Great Commission. Over 95\% of all respondents agreed that a sports ministry would have a positive impact on evangelism. The results of the survey showed that the participants from the churches in Pretoria are supportive of a sports ministry as a general strategy to help churches to promote evangelism and outreach, to cross cultural barriers, to keep in touch with society and to provide a place for teaching life skills and develop leaders.

\section{Introduction}

At the end of the 19th century, sports ministry (in the guise of Muscular Christianity) was growing and playing a vital and vibrant role in churches in Western countries and through missionaries entering foreign nations. However, the momentum slowed down and Christians began to turn their backs on sports ministry - even becoming overtly critical of Christians participating in sport. As the 20th century dawned, sport became even more popular and powerful. As sports stars gained fame and fortune, the church began to turn its back on what it had previously embraced. The church viewed its embracing of sport as having backfired. Sport was becoming popular at the expense of faith, with many viewing sport as becoming a religion in and of itself (Connor 2003:4, 32).

In the mid-20th century, with the United States of America (USA) leading the way, the church started to re-engage with the world of sport, recognising the potential of impacting the world for Christ through sports outreach. This rebirth gave rise to the term 'sports ministry' (Mason 2003:20). Factors that led to this re-engagement include the following: church-based sports and recreation ministries, celebrity sports - people being used to attract a crowd at crusades - sports mission teams travelling from the USA to other countries, specialised sports ministries being established to reach sports people with the Gospel and outreach taking place at major sporting events, such as the Olympic Games and the FIFA World Cups (Ladd \& Mathisen 1999:112-115, 135, 140; McCown \& Gin 2003:116-117, 119-120, 122-123, 125-126, 128).

The FIFA World Cup ${ }^{\mathrm{TM}}$ boasts of being the largest sporting event on the planet. In 2004 FIFA awarded the 2010 event to South Africa. As 2010 approached, churches across South Africa began to consider what role they could play, particularly in developing strategies for evangelism and community outreach during this major sporting event (cf. Tucker 2011:4). The 2010 FIFA World Cup ${ }^{\mathrm{TM}}$ clearly provided a unique window of opportunity for the renewed engagement between the church and the world of sport in South Africa.

The World Cup offered churches in South Africa a way to impact their community, particularly through sports outreach. As a result they fostered what became known as The Ultimate Goal - a network of churches and agencies working together to bring hope and change to South Africa. Under the leadership of its CEO, Joseph Jacobs, the vision was large. The Ultimate Goal initiative set out to train people from 2000 churches in 600 towns and cities in South Africa to run sports-based outreach programmes. They planned to reach 14 million people in some way during the course of the Word Cup. The Ultimate Goal generated teams that mobilised prayer, generated volunteers, and facilitated mission teams including those using creative arts. They also helped more than 200 churches to stage big-screen showings of the World Cup soccer matches in 
community centres, the open air, in schools, town halls and on their own premises - something entirely new for South Africa (Meadows 2011).

What was the impact of the Ultimate Goal initiative? Firstly, new relationships were formed between churches. The World Cup brought co-operation that had never been seen before. Revd Nico Swart, a Dutch Reformed Church Minister and the convener of World Cup initiatives for the Mamelodi district of Pretoria said, 'In the past, churches have been afraid of each other. In the context of nation-building, the World Cup has given us the opportunity to build new relationships' (Meadows 2011).

Secondly, new coalitions were formed, including those relating to the issue of social justice and a new network of creative arts ministries. Thirdly, hundreds of churches tasted the benefit of a sports ministry and numerous people were trained to participate in the programmes. As a result of the interest generated by The Ultimate Goal, some churches launched their own initiatives. For example, one church in Pretoria, the Eastside Community Church, developed a Holiday Club resource based on the World Cup that was being used by over 400 churches. They also equipped 10 trailers with everything required for a far-flung rural community to have a sports clinic and a big screen for showing a World Cup soccer match - plus sharing the Gospel (Meadows 2011).

Sport can be defined as, 'all forms of physical activity that contribute to physical fitness, mental well-being and social interaction. These include play, recreation, organized, casual or competitive sport, and indigenous sports or games' (Sicroff 2011).

\section{A sports ministry is any competitive or non-competitive:}

activity that takes place during leisure time with the stated purpose or intention of helping people become aware of their need for a relationship with God, his daily role in their lives and their place in his kingdom work. (Garner 2003:10)

This article reports on a study by Tucker (2011), which was aimed at identifying the motivational factors that promote a sports ministry in the church context. The churches in Pretoria were used as a case study for the empirical research. The goal of the study was to investigate the church leaders' perceptions regarding the motivational factors for a sports ministry in selected churches in Pretoria.

\section{Theological motivations for a sports ministry Creation}

A focus on creation as a theological motivation for sports ministry has both a macro and micro emphasis. On the macro level sport is considered as part of God's created order and therefore He can be glorified through sport as through all of His creation (Oswald 2002:10). On a micro level, the people who pursue sport are regarded as made in the image of God and therefore the sporting gift in itself is viewed as part of being an image-bearer. Drawing from Genesis 1:27, the gift and ability of sport is valued, because sportsmen can recognise that they have been 'uniquely designed by their Creator, genetically wired to move, to crave competition, to be instinctively active, and to be energised by challenges' (McCown \& Gin 2003:28).

McCown and Gin (2003:28) also draw from the imagery of Psalm 139:13. God has knit the sports person together in a specific way, created to enjoy the gift of sport, and through utilising the gift, bring glory to God. Thus, participation in sport can in itself be viewed as an expression of being made in God's image and part of the dignity assigned to being the pinnacle of God's creation (Oakley 2005:15).

\section{Worship}

Weir argues that worship should not be regarded as an event that takes place in church, but to encompass everything the Christian does, including sport. He highlights Romans 12:1-2 as a biblical mandate to offer God worship in everything we do. Sport provides a very physical way in which one's body can be offered as a 'living sacrifice'. Weir appeals to the Westminster confession which states that man's chief purpose is to bring glory to God, and asks the question: 'Is there any reason why that should not be on a sports field just as much as in a church?' (Weir 2000:31, 32).

Through this focus on sport as an act of worship, the sports ministry movement places tremendous value on participation in sport, which has implications for how sport is to be played. It is maintained that if sport is truly a gift of God, then Christian people who pursue sport, in honouring the giver of the gift, should participate in a way that is pleasing to him (Daniels \& Weir 2008:3). Many sports ministry theologians draw on a quote by Eric Liddell (1902-1945) who was a top sprinter before the 2nd World War and was widely acclaimed for his Christian testimony (Wilson 1996:32). In the film Chariots of Fire Liddell is quoted as saying, 'God made me fast. When I run, I feel His pleasure' (McCown \& Gin 2003:45).

\section{Redemption}

Rodger Oswald in Garner (2003:27) focuses on the mandate that Christians have to proclaim the Good News to all nations and thus fulfil the commission given by Christ in Matthew 28:19. Given that sport transcends all nations, cultures and languages, it is therefore a powerful medium through which the Gospel can be taken to the ends of the earth (Daniels \& Weir 2008:5). This theme of redemption is taken further by other sports ministry apologists who view the world of sport as the object of redemption in Christ (Daniels \& Weir 2008:2) and therefore, sport itself is being restored to the place of bringing glory to God (The World of Sport Today 2006:65).

McCown and Gin call this the 'sports-valued approach'. They argue that sport is not just a tool to proclaim the redemptive message, but that sport itself can and should, be redeemed. This focus changes the approach of those involved in sports 
ministry from simply pragmatically utilising sport as an opportunity for evangelism, to valuing sport 'in and of itself' because 'sport has value simply because God created people of sport who are wired to live, move, and be' (McCown \& Gin 2003:30).

\section{Liberty and expediency}

The theological emphasis on liberty that comes through the writings of modern sports ministry writers builds upon the text of 1 Corinthians 9:19-23. Here Paul justifies the different means he used to reach people with the Gospel. Whether he be reaching Jews, Greeks, Gentiles, slave or free, the Apostle would utilise a method that most suited the audience he was seeking to impact (Oswald 2002:11).

Oswald uses the word 'expediency' to describe this approach to ministry. He defines expediency as 'excelling in all things to accomplish the greatest results.' He goes on to argue that, as the apostle Paul utilised the best method to get the maximum result, so the church today needs to consider sport as one of the principle methods for evangelism in today's world (Oswald 2002:7,11). David Oakley (2005:18) calls this approach the 'liberty principle'. God has given Christians freedom to find the best means to reach people with the Gospel.

\section{The research problem}

Since the early 20th century, South African churches have been mostly disengaged from sport. However, in the past thirty years there has been a gradual re-engagement between Christians and sport in South Africa, but this has been largely led by para-church and mission organisations, such as Sport for Christ Action South Africa (SCAS) and Athletes in Action (AIA). Both of these organisations (formed in the 1980s), and others similar to them, predominantly worked within the world of student and professional sports, rather than through local churches. Due to the recent focus on the 2010 FIFA World Cup ${ }^{\mathrm{TM}}$ in South Africa, a renewed engagement between the church and sport is occurring, as more and more churches are developing sports outreach programmes. Some churches have formed sports teams and these play in so-called 'Christian Leagues', while other churches provide opportunities for recreational sport. However, it is still quite rare today to find a church with a specialist sports ministry department (cf. Tucker 2011:3,4).

This paper focuses on the following research problem: What are the perceptions of the church leaders regarding the motivational factors for a sports ministry in selected churches in Pretoria?

\section{Research methodology \\ Structured and semi-structured questionnaires}

This study ${ }^{1}$ made use of a two-part questionnaire relating to how church leaders in Pretoria perceive the motivational

\footnotetext{
1.Permission was granted by the South African Theological Seminary to conduct this study. The respondents freely consented to participate in this study. They were aware of the aims and objectives of the study. The names of the respondents have aware of the aims and objectives of the study. The names of the respondents have
not been divulged. The records of the structured interviews conducted with the respondents are safely stored away by the authors.
}

factors for a sports ministry in the church. These motivational factors were based on Oswald's (2002:2) motivations for developing a church-based sports ministry.

Part 1 of the questionnaire consisted of a structured questionnaire for the collection of quantitative data regarding the ranking of ten motivational factors in order of significance. Part 2 comprised a semi-structured questionnaire (with open-ended questions) for obtaining qualitative feedback regarding the reasons why the respondents perceived each motivational factor as being important.

Once all the questionnaires had been completed and returned, the data was recorded and collated in preparation for analysis. In the quantitative survey, the data from the structured questionnaire (Part 1) was converted into a score out of 20 for better analysis, indicating the significance of the ten motivational factors for a sports ministry in the church, as perceived by the respondents. In the qualitative survey (Part 2) data from the semi-structured questionnaire was analysed by considering the words recorded by the respondents. Trends and patterns relating to the top four motivational factors that were perceived as being important were placed into categories. Eventually, different themes relating to these motivational factors emerged.

\section{Sampling method}

The sampling method used in this research was purposive sampling, which aims to ensure that the sample is selected on the basis of diversity, for example, selecting representatives from different denominational, regional and ethnic groups in Pretoria.

Purposive or judgemental sampling is a common nonprobability method, whereby the researcher selects the sample based on judgement. Purposive sampling is used in cases, where it can be argued that an authority (based on his or her expertise) can select a more representative sample that can produce more accurate results than can be achieved using other probability sampling techniques. The two main weaknesses of purposive sampling are reliability and bias (Castillo 2009).

The church leaders who participated in this study were connected to The Ultimate Goal (TUG) Pretoria. This network was chosen because it contained a wide demographic representation of churches in Pretoria and because of the interest that was shown by these church leaders in utilising the FIFA World Cup ${ }^{\mathrm{TM}}$ for evangelism. The sampling frame for this study was 32 church leaders from 26 churches in Pretoria which represented a wide variety of denominational and cultural backgrounds. Table 1 below provides the basic demographic details of the churches that these leaders represented and demonstrates that the sample was representative of the church communities across Pretoria.

\section{Pilot study}

Before proceeding with the empirical survey, a pilot study was conducted in order to pre-test the questionnaires to be 
TABLE 1: Demographic details of the churches represented by the respondents.

\begin{tabular}{|c|c|c|c|c|}
\hline Church Name & Denomination & Suburb & Membership & Ethnicity \\
\hline Eaststide Community Church & Baptist & Garsfontein & 220 & White people \\
\hline Pretoria East NGK & Dutch Reformed & Arcadia & 2500 & White people \\
\hline Hatfield Christian Church North & N/A & Pretoria North & 2500 & Black people and White people \\
\hline St Johns & Church of England in South Africa & Queenswood & 100 & Various ethnic groups \\
\hline Bethesda Revival Church & Full Gospel Church of God in South Africa & Laudium & 500 & Indian people/Coloured people/Black people \\
\hline Ekklesia AOG & Assemblies of God & Eersterust & 100 & Coloured people and Black people \\
\hline Central Baptist Church & Baptist Union & Arcardia & 375 & Various ethnic groups \\
\hline Moreleta NGK & Dutch Reformed & Moreleta Park & 15000 & White people \\
\hline Capital Park NGK & Dutch Reformed & Capital Park & 430 & White people \\
\hline Lewende Woord & Independent & Brummeria & 8000 & White people \\
\hline Emanuel Presbyterian Church & Presbyterian & Faerie Glen & 350 & White people \\
\hline Pretoria Salvation Army & Salvation Army & Pretoria West & 100 & Various ethnic groups \\
\hline Reformed Church in Africa & Reformed Church in Africa & Laudium & 180 & Various ethnic groups \\
\hline Restoration Bible Church & Independent & Mamelodi & 150 & Black people \\
\hline Choose Life & Charismatic & Garsfontein & 1600 & White people \\
\hline Lynnwood Ridge NGK & Dutch Reformed & Lynnwood & 3000 & White people \\
\hline Outreach Christian Community Church & Independent & Centurion & 600 & Black people \\
\hline Riviera Community Church & Grace Communion International & Riviera & 65 & Black people and White people \\
\hline Elloffsdal Assembly & Full Gospel Church of God in SA & Ellofffsdal & 120 & White people \\
\hline New Life Conquerors Church & Charismatic & Mamelodi & 180 & Black people \\
\hline Garankuwa Church & Independent & Garankuwa & 120 & Black people \\
\hline Melodi ya Tshwane & Uniting Reformed Church & Vermeulen & 2359 & Black people \\
\hline Waverley Oos NGK & Dutch Reformed Church & Waverley & 1150 & White people \\
\hline Free Methodist church & Free Methodist & Pretoria & 1000 & Black people \\
\hline St Albans Cathedral & Anglican & Pretoria & 780 & Black people \\
\hline
\end{tabular}

used as measuring instruments to discover whether there were any deficiencies in the questionnaires and if revisions were required (Smith 2008:235). The questionnaires were distributed to ten people, comprising colleagues of one of the researchers with experience in sports ministry, and pastors from outside the geographical area of study. Those included in the pilot study were not only asked to complete the questionnaires, but were also requested to give their feedback on any areas of ambiguity and their recommendations for improvements. Their input helped to finalise the final drafts of the questionnaires in preparation for distribution.

\section{Research findings}

The biographical data of the respondents will be presented first, followed by the findings of the structured questionnaires (Part 1) and the findings of the feedback received from the semi-structured questionnaires (Part 2) as they emerged into specific themes.

\section{Biographical profile of respondents}

The biographical profile reflects the respondents' gender, role and length of service in the church, denomination and the size and ethnicity of church.

\section{Gender}

Figure 1 shows the distribution of respondents according to gender.

It is clear from Figure 1 that the respondents to the survey were predominantly male. Given that the questionnaires were aimed at full-time church leaders or pastors, this was perceived to be representative of church tradition in Pretoria.

\section{Role in the church}

Figure 2 shows the distribution of respondents according to their role in the church.

Figure 2 indicates that all the respondents were in significant leadership positions in the church. Fifty percent identified themselves as being the senior pastor, with the remaining $50 \%$ divided between various leadership functions.

\section{Period of service in the church}

Figure 3 shows the distribution of respondents according to their period of service in the church.

It was important for the survey to have a good spread in terms of period of service in the church. Of the respondents, $12.5 \%$ had served in their church for over 15 years, whereas $43.75 \%$ were relatively new in their church, having served for between 0 and 4 years. A further $43.75 \%$ had served between 5 and 14 years. The variance in experience and period of service was vital to obtain good representative data.

\section{Church Denomination or Tradition}

Figure 4 shows the distribution of respondents according to their church denomination or tradition.

It is clear from Figure 4 that the church leaders came from a wide variety of church denominations and traditions, 
which constitutes a representative sample of the churches in Pretoria.

\section{Church size or number of members}

Figure 5 shows the size of the respondent's churches based upon their number of members.

Although it is recognised that the respondents may have differing understandings of the interpretation of the word 'members', Figure 5 does demonstrate that the respondents represented a wide variety of church sizes.

\section{Ethnicity}

Figure 6 shows the predominant ethnic grouping of the respondent's church members.

The ethnic groupings listed are those generally utilised in the South African context, namely, Black people, White people, Coloured people and Indian people, which serves to demonstrate, for the purposes of this survey, that all ethnic groups were represented.

\section{Results from structured questionnaire (Part 1)}

This section deals with the responses given by the church leaders regarding the significance of the ten motivational factors for a sports ministry in the church. The statistical analysis of the gathered data was done by calculating the score out of 20 of each of the ten motivational factors listed in the structured questionnaires. Figure 7 shows the significance of each motivational factor for a sports ministry in the church as perceived by the church leaders in Pretoria on a scale of $1-20$.

\section{Themes from the semi-structured questionnaires (Part 2)}

This section deals with the responses given by church leaders regarding the reasons why the top four motivational factors were perceived as important. The themes that emerged from the feedback from the semi-structured questionnaires regarding the top four motivational factors for a sports ministry in the church are as follows:

\section{Theme 1: Evangelism}

The following sub-themes were identified:

\section{Sport creates an environment for outreach:}

'We are commanded to go into the world and make disciples of all nations. Soccer gives a great opportunity to do that. We have Paul's example of being all things to all men for the sake of the Gospel, which applies to soccer in our country today. We are told to let our light shine and be the salt of the earth so as to make the Gospel attractive and produce the fruits of its truth soccer creates an environment for this to happen, for the sake of the Gospel.'

The sports arena is an ideal place for reaching un-churched people:

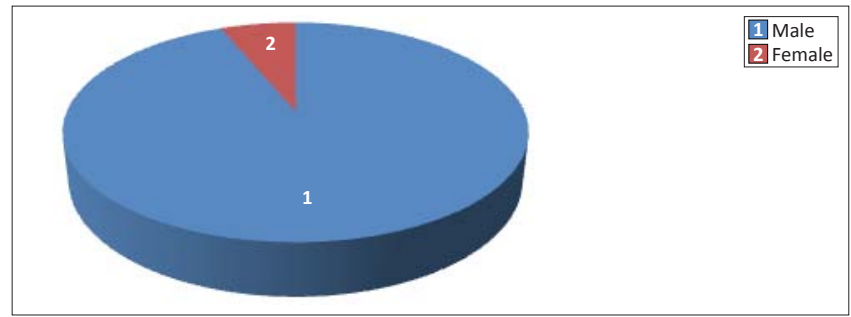

FIGURE 1: Distribution of respondents according to gender.

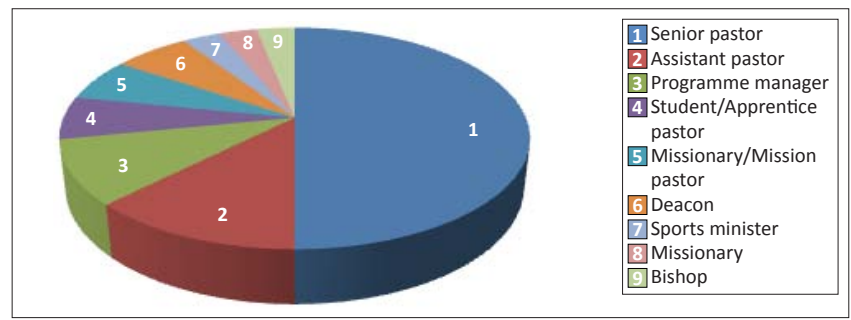

FIGURE 2: Distribution of respondents according to their role in the church.

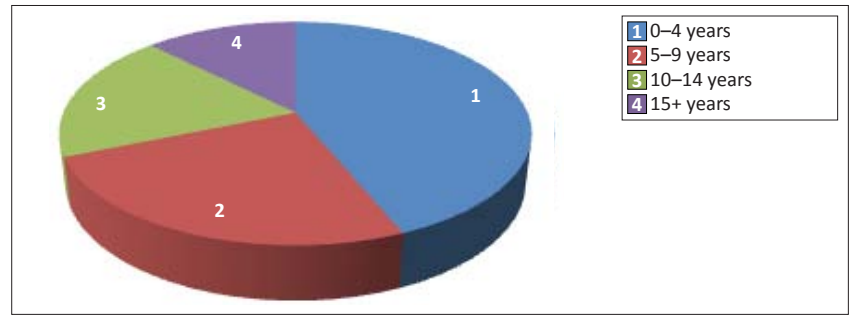

FIGURE 3: Distribution of respondents according to their period of service in the church.

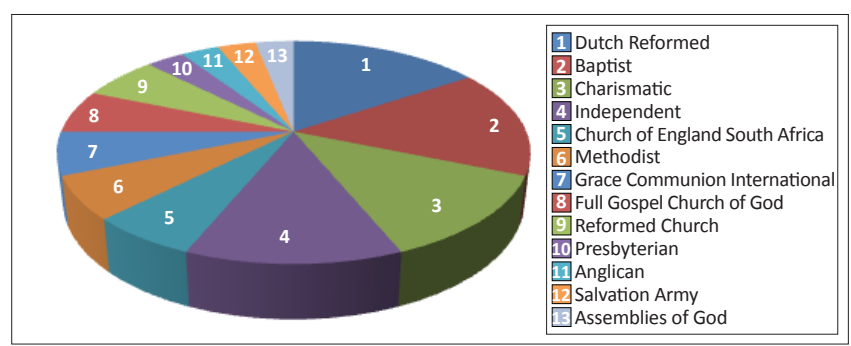

FIGURE 4: Distribution of respondents according to their church denomination or tradition.

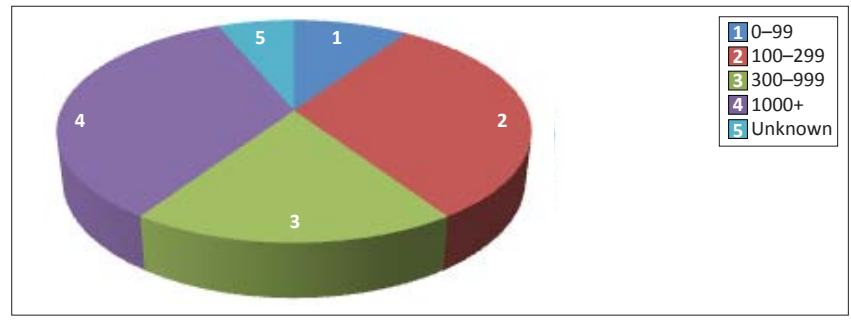

FIGURE 5: Distribution of respondents according to the size of their church.

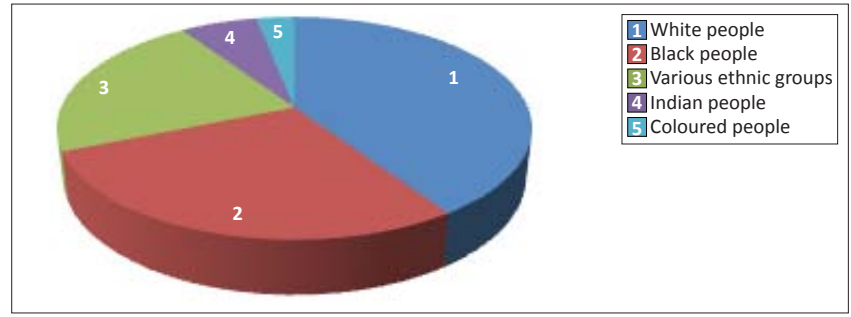

FIGURE 6: Distribution of respondents according to the predominant ethnicity of their church. 


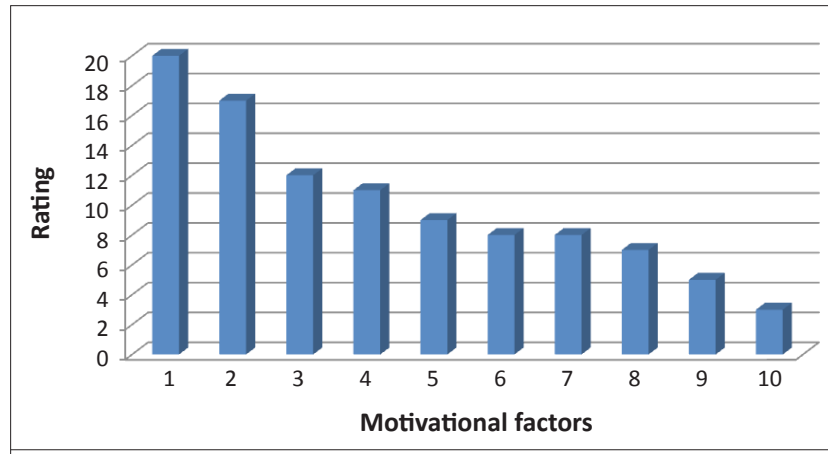

Top 10 Motivational factors:

1. Assists the church with evangelism and fulfilling the Great Commission.

2. Helps the church to cross cultural and other barriers, thus extending its influence.

3. Keeps the church in touch with society and culturally relevant.

4. Provides a place for teaching life skills and developing leaders.

5. Gives people a vision and heart for reaching the lost.

6. Keeps people from drifting from the church - particularly young people.

7. Brings transformation and Kingdom values to the world of sport.

8. Provides an 'entry level' of service for new believers.

9. Contributes to the 'body-life' and the fellowship aspect of the church.

10. Provides the opportunity for planting cell groups and ultimately planting churches.

FIGURE 7: Motivational factors for a sports ministry in the church.

'Evangelism is a reaching out to a people who are in need of a change in behaviour and the sports arena is an ideal place to meet un-churched people.'

Use any strategy, including soccer, if it helps to promote the Gospel:

'It was commanded and it should be done no matter what strategy we use as long as it is not against God's principles we can use it.'

\section{Theme 2: Crossing barriers}

Playing sport with Christians from other cultures promotes unity:

'This is one of our biggest challenges in South Africa. Sport gives an opportunity for people to play together. It also gives an opportunity for Christians to play together and show solidarity in Christ across cultural barriers.'

Sports ministry breaks down all kinds of barriers to evangelism:

'I agree sports ministry creates the greatest avenues to break down every kind of barrier; the church can move into cultural evangelism and makes cross-cultural evangelism easily accessible to reach the lost. Sportsmen are the great ambassadors for Christ.'

Sport brings people of different cultures together:

'In sport there are no barriers. People speak the same language. In sport, there is no discrimination, people support one another. Encourage each other. Sport brings different people and cultures together (Philippians 2:1-11).'

\section{Theme 3: Social and cultural impact}

Sports ministry helps the church to be socially relevant:

'Sport, particularly in South Africa has reached idol status. People actually plan their days and weekends around sport. It therefore is something impacting the community and society so for the church to remain relevant it is important to have a sports ministry.'
The church could use the language of sport to convey the Gospel:

'One of the languages spoken in our communities is sports. I believe if the church could use the sports language to bring the message of the cross, it will be understood by many.'

Sports ministry helps to connect believers with the real world:

'It connects theology and real life. It connects believers with unbelievers. It connects protected clergy to the real world.'

\section{Theme 4: Developing life skills and leaders}

Teamwork and leadership skills are learned by participation in sport:

'Sports give opportunity to discover and develop leaders. Teamwork and leadership skills are needed to develop a good team and these can be learned by participation in sports. Life skills can be taught through this means and modelled by coaches and Christian players.'

Sports metaphors are good tools for teaching life skills:

'Sports are great tools to teach: physically, mentally and spiritually. Paul even uses sports metaphor to express the achievement of life.'

The sports field is an ideal place for training the youth in life skills:

'Proverbs 22:6 teaches us that we need to train up a child in the way he should go, and he will have direction for his future. Life skills are an essential part of this "train up" that needs to take place. The sports field affords players the opportunity to apply their knowledge and skills cultivating wisdom.'

\section{Key findings}

Determining the motivational factors for a sports ministry in a church is vital for effective planning. The respondents confirmed that the most important motivational factors for a sports ministry in a church are as follows:

'It assists the church with evangelism and fulfilling the Great Commission; it helps the church to cross cultural and other barriers, thus extending its influence; it keeps the church in touch with society and culturally relevant, and it provides a place for teaching life skills and developing leaders.'

These motivational factors correlate with the theological motivations for a sports ministry. For example:

- The theological motivation of Redemption, described in terms of the Christian's mandate to proclaim the Good News to all nations (Garner 2003:27), is closely related to the motivational factor of evangelism and fulfilling the Great Commission.

- The theological motivation of Liberty and Experience, described in terms of using different means to reach people with the Gospel (Oswald 2002:1), correlates with the motivational factor of using sport to cross cultural and other barriers for the purpose of evangelistic outreach.

- The theological motivation of Worship, described in terms of the testimony of Christian sportsmen (Wilson 1996:32), 
is similar to the motivational factor of being socially and culturally relevant.

- The theological motivation of Creation, described in terms of helping people to use their sporting gift as an expression of being image-bearers of God (Oakley 2005), corresponds with the motivational factor of using sport to teach life skills and to develop leaders.

\section{Conclusion}

In this empirical survey it was observed that the most frequently selected motivational factor for developing sports ministry was that sports ministry could assist the church in fulfilling the Great Commission. The second most frequently selected motivation was that sports ministry could help the church cross cultural barriers thereby extending greater influence in the community and engaging in mission. Both of these motivations are highly evangelistic in nature and therefore demonstrate that the church leaders in Pretoria believe that sports ministry is essentially evangelistic and missional in nature.

Church leaders in Pretoria clearly recognise sport as an opportunity for evangelism. The focus on the FIFA World Cup $^{\mathrm{TM}}$ in 2010 provided a challenge to the churches to channel their enthusiasm beyond the event into a long-term sports ministry. It is the hope of the authors that perceptions of the church leaders regarding the motivational factors for a sports ministry, could be used by other church leaders as guidelines for designing a practical strategy to develop a sustainable sports ministry in their churches.

This preliminary research of motivational factors for a sports ministry is mainly descriptive, and simply points to the openness on the part of church leaders in Pretoria to the potential of sports ministry in the church context. Clearly, further research is required to determine the efficacy of sports ministry in the local church context. It is one thing for church leaders to perceive that sports ministry is effective for evangelism. However, it is quite another thing to demonstrate that it is effective in practice.

\section{Acknowledgements Competing interests}

The authors declare that they have no financial or personal relationship(s) which may have inappropriately influenced them in writing this article.

\section{Authors' contributions}

N.W. (South African Theology Seminary) was the project leader, N.W. and T.T. (Ambassadors in Sport) were jointly responsible for the research project design and for conceptual contributions, T.T. conducted the empirical survey and performed the data analysis, N.W. wrote the manuscript in close collaboration with T.T.

\section{References}

Castillo, J.J., 2009, 'Judgmental sampling', viewed 02 February 2012, from www. experiment-resources.com/judgmental-sampling.html\#ixzz1IDGLKTWP

Connor, S., 2003, Sports Outreach: Principles and Practice for Successful Sports Ministry, QUE Publishing, Ross-shire.

Daniels, G. \& Weir, W., 2008, 'Church and Sport', viewed 28 April 2009, from http:// www.veritesport.org

Garner, J. (ed.), 2003, Recreation and Sports Ministry: Impacting Postmodern Culture, Broadman \& Holman Publishers, Nashville, TN.

Ladd, T. \& Mathisen, J. A., 1999, Muscular Christianity, Baker Books, Grand Rapids, MI.

Mason, B., 2003, Into the Stadium, Milton Keys, Spring Harvest Publishing Division, Bucks.

McCown, L. \& Gin, V.J., 2003, Focus on Sport in Ministry, 360 Sports, Marietta, GA.

Meadows, P., 2011, 'World Cup church response in South Africa has 2012 lessons', Inspire magazine, viewed 20 October 2011, from www.inspiremagazine.org.uk/ news. aspx?action=view\&id=4591

Oakley, D., 2005, 'An examination of how the role of the Spirit as seen in Galatians might help Christians who participate in competitive sport', Masters Dissertation, Applied Theological Studies Department, Regents College.

Oswald, R., 2002, 'Sports Ministry and the Church' unpublished paper, Church Sports International, Campbell, CA.

Sicroff, S., 2011, 'The Sport for Development and Peace Mission', Moving Mountains: Journal of Sport for Development and Peace, viewed 20 October 2011, from www. sportdevelopmentpeace.org/0mm-commentary.htm

Smith, K.G., 2008, Academic Writing and Theological Research: A Guide for Students, South African Theological Seminary Press, Johannesburg.

The World of Sport Today, 2006, Libreria Editrice Vaticana, Cittá del Vatticano.

Tucker, T., 2011, 'A strategy for the development of a sustainable sports ministry using mission outreach through soccer in selected churches in Tshwane', MTh dissertation, Practical Theology Department, South African Theological Seminary.

Weir, J.S., 2000, What the Book says about Sport, Bible Reading Fellowship, Oxford.

Wilson, J., 1996, Complete Surrender, Monarch Publications, East Sussex, UK. 